\title{
PENGEMBANGAN VIDEO BAHAN AJAR SIPEJAR PADA PERKULIAHAN BLENDED LEARNING SUPERVISI PENGAJARAN MELALUI MODEL PEMBELAJARAN PROBLEM BASED ROLE PLAYING (PBRP)
}

\author{
Dedi Prestiadi \\ Maisyaroh \\ Wildan Zulkarnain \\ Ahmad Nurabadi \\ Imron Arifin \\ Athalla Nauval Bhayangkara \\ Universitas Negeri Malang, Jalan Semarang 5 Malang 65145 \\ E-mail: dedi.prestiadi.fip@um.ac.id
}

\begin{abstract}
Purpose of this study was to develop a video of SIPEJAR teaching materials in teaching supervision lectures through various tests on (1) video teaching materials and (2) learning syntax. The various research procedures used by the research team in this development use a modified research and development approach by Borg \& Gall. The data collection instruments used in this study were questionnaires and expert validation sheets. The data analysis process in this study used quantitative descriptive. The data generated from the distribution of student questionnaire instruments were analyzed using standard formulas to describe learning problems, while in the feasibility test of existing products also used descriptive analysis through standard formulas to examine whether the product presented was feasible or not. The results in this study indicate that (1) the role-playing video for teaching supervision learning was assessed both by the first and second experts, (2) the role-playing video was considered good by the students, (3) the results of the different test showed that there was no difference in the perception of assessment between students. male and female, (4) the results of expert validation regarding the revised learning syntax were considered good, (5) the learning syntax which was originally 7 stages was revised into 6 stages. Then the theoretical-based review results state that (1) the PBRP model meets various criteria for good teaching materials, (2) the PBRP model has a long positive impact as a stimulus for students' 4C skills, student mental attainment, and student self-efficacy.
\end{abstract}

Keywords: Blended learning; instructional model; Educational Supervision

\begin{abstract}
Abstrak: Tujuan penelitian ini adalah untuk mengembangkan video bahan ajar SIPEJAR pada perkuliahan supervisi pengajaran melalui berbagai pengujian terhadap (1) video bahan ajar dan (2) sintak pembelajaran. Berbagai prosedur penelitian yang digunakan oleh tim peneliti pada pengembangan ini menggunakan pendekatan $r \& d$ atau research and development Borg \& Gall yang telah dimodifikasi. Instrumen pengumpulan data yang digunakan dalam penelitian ini adalah angket dan lembar validasi ahli. Proses analisis data dalam penelitian ini menggunakan deskriptif kuantitatif. Data yang dihasilkan dari sebaran instrumen angket mahasiswa dianalisis menggunakan formula stanfive untuk mendeskripsikan permasalahan pembelajaran, sedangkan dalam uji kelayakan produk yang ada juga menggunakan analisis deksriptif melalui rumus stanfive guna menelaah apakah produk yang disajika layak atau tidak. Hasil dalam penelitian ini menunjukkan bahwa (1) video bermain peran untuk pembelajaran supervisi pengajaran dinilai baik oleh ahli pertama dan kedua, (2) video bermain peran dinilai baik oleh mahasiswa, (3) hasil uji beda, menunjukkan tidak ada perbedaan persepsi penilaian antara mahasiswa laki-laki dan perempuan, (4) hasil validasi ahli mengenai sintak pembelajaran revisi dinilai baik, (5) sintak pembelajaran yang awalnya
\end{abstract}


7 tahap direvisi menjadi 6 tahap. Kemudian hasil telaah theoritical based menyatakan bahwa (1) model PBRP memenuhi berbagai kriteria bahan ajar yang baik, (2) model PBRP memiliki dampak positif panjang sebagai stimulus adanya keterampilan 4C siswa, mental attainment siswa, dan efikasi diri siswa.

Kata kunci: Blended learning; Model Pembelajaran; Supervisi Pendidikan

Perkembangan teknologi informasi dan komunikasi memberikan pengaruh terhadap proses pembelajaran di dalam lembaga pendidikan. Pemilihan strategi dan metode pembelajaran yang tepat sesuai dengan karakteristik peserta didik akan sangat membantu guru dalam melaksanakan proses pembelajaran. Oleh karena itu diperlukan langkah inovatif dari guru untuk terus mengembangkan metode pembelajaran sehingga tercipta proses pembelajaran yang efektif. Penggunaan media-media pembelajaran yang berbasis online merupakan karakter pendidikan dewasa ini, dimana pembelajaran lebih banyak memadukan antara pembelajaran online dengan pembelajaran cara lama melalui tatap muka di kelas (Prestiadi, Maisyaroh, Arifin, \& Bhayangkara, 2020).

Pemilihan model pembelajaran merupakan faktor penting terhadap kesuksesan pencapaian tujuan pembelajaran. Kemampuan guru dalam memilih dan menggunakan model pembelajaran dikelas menjadi sangat penting dalam rangka menciptakan proses belajar yang efektif. Sesuai dengan pandangan teori interaksional mendefinisikan pembelajaran sebagai proses interaksi peserta didik dengan pendidik dan sumber belajar yang terdapat di dalam lingkungan belajar. Proses belajar dianggap memiliki kualitas baik apabila terjadi proses interaksi yang bersifat multi arah, yakni antara guru dengan peserta didik, peserta didik dengan peserta didik, peserta didik dengan lingkungan belajar, serta peserta didik dengan sumber belajar (Nurdyansyah dan Eni Fariyatul Fahyuni, 2016).

Pembelajaran pada era perkembangan teknologi informasi dan komunikasi menuntut adanya langkah inovatif yang dapat memanfaatkan berbagai macam teknologi yang dapat digunakan dalam menunjang kegiatan pembelajaran. Pembelajaran pada saat ini bukan hanya pembelajaran seperti era klasik dimana peran guru lebih domininan dibandingkan dengan siswa. Artinya, pembelajaran yang lebih memberikan kesempatan kepada siswa untuk mengkonstruksi pengetahuan secara mandiri dan dimediasi oleh teman sebaya (Prestiadi, Maisyaroh, Zulkarnain, et al., 2020).

Menurut (Anggraeni, 2018) dalam proses pembelajarannya, semua siswa harus terlibat penyelidikan aktif dengan mengajukan pertanyaan, perencanaan investigasi, mengumpulkan data, menggunakan pengetahuan secara ilmiah untuk memahami data hasil pengamatan, dan mengkomunikasikan hasil temuannya. Selain keterlibatan aktif peserta didik juga diperlukan pemahaman konsep dalam proses belajar mengajar karena dapat mempengaruhi sikap, keputusan, dan cara-cara memecahkan masalah. Pembelajaran yang berkualitas adalah pembelajaran yang mampu menciptakan keaktifan serta kebermaknaan bagi peserta didik, sehingga apa yang dipelajari bukan hanya sebatas pada transfer pengetahuan (knowledge transfer), tatapi juga terjadinya proses transfer sikap (value transfer).

Pada realitanya masih dijumpai pola-pola pembelajaran yang hanya menekankan pada pemahaman tentang konsep saja, sehingga mahasiswa kurang mampu menggunakan konsep tersebut jika menemui masalah dalam kehidupan nyata yang berhubungan dengan konsep, bahkan sampai kurang mampu menentukan masalah dan merumuskannya. Berdasarkan permasalahan tersebut, maka diperlukan sebuah kajian dan pengembangan proses pembelajaran yang mampu menemukan cara terbaik untuk menyampaikan berbagai konsep atau materi-materi yang diajarkan kepada mahasiswa, sehingga mahasiswa dapat menggunakan dan mengingat lebih lama konsep atau materi-materi tersebut.

Pembelajaran berbasis masalah merupakan pendekatan yang efektif untuk pembelajaran proses berpikir tingkat tinggi yang sangat cocok digunakan pada proses pembelajaran di perguruan tinggi. Pembelajaran ini membantu mahasiswa untuk memproses informasi yang sudah jadi dalam benaknya dan menyusun pengetahuan mereka sendiri tentang dunia sosial dan sekitarnya. Melalui pembelajaran ini mahasiswa dituntut untuk dapat mengembangkan pengetahuan dasar maupun kompleks untuk dapat menganalisis permasalahan-permasalahan yang kemudian dapat digunakan sebagai bahan analisis dan diskusi untuk merancang alternatif pemecahan masalah melalui pembelajaran di kelas. 
Pembelajaran berbasis masalah masih perlu dilakukan pengembangan sehingga mahasiswa tidak hanya mampu untuk menganalisis permasalahan dan memecahkan permasalahan secara konseptual tetapi juga mampu untuk secara langsung terampil dan memiliki pengalaman dalam memecahkan permasalahan. Salah satu pendekatan model pembelajaran yang dapat memberikan pengalaman kepada mahasiswa adalah dengan menggunakan model bermain peran (role playing). Model pembelajaran role playing untuk proses pembelajaran di kelas bisa menjadi pengalaman yang berguna bagi dosen dan mahasiswa dan akan meningkatkan pembelajaran (Greenberg, E. and Miller, 1991)

Penelitian yang dilakukan oleh (Armstrong, 2003) memberikan kesimpulan bahwa model pembelajaran role playing proses pembelajaran bukan hanya sebatas pada transfer pengetahuan tetapi juga akan terjadi proses transfer pengalaman kepada mahasiswa (Armstrong, 2003). Model role playing dapat memancing pikiran dan perasaan untuk berpikir menghubungkan ide dan pengalaman bersamasama dengan membuat koneksi logis, dan cenderung impersonal. Perasaan melibatkan menimbang manfaat relatif dari nilai-nilai dan sikap dari kedua individu dan kelompok (Yehuda Baruch, 2006).

Pentingnya menciptakan pembelajaran yang dapat menumbuhkan sikap kritis mahasiswa untuk dapat berkolaborasi dengan sesama dan kemampuan menganalisis, memecahkan masalah serta memberikan pengalaman pada mahasiswa sehingga pembelajaran lebih bermakna. Berdasarkan pandangan tersebut maka perlu adanya pengembangan model yang mampu memadukan kedua model pendekatan tersebut. Penggabungan kedua model tersebut dinamakan sebagai model pembelajaran Problem Based Role Playing (PBRP) (Errington, 1997). Model pembelajaran PBRP bertujuan untuk mengembangkan pembelajaran aktif dan kolaboratif sehingga dapat diterapkan dalam proses pembelajaran. Selain itu penggabungan kedua model tersebut melalui PBRP dapat melatih keterampilan dan pengalaman bagi mahasiswa dalam memecahkan masalah yang disesuaikan dengan materi perkuliahan.

Adanya model pembelajaran bermaian peran berbasis masalah diharapakan bisa meningkatkan pemahaman materi perkuliahan, khususnya dalam matakuliah Supervisi Pengajaran di Jurusan Administrasi Pendidikan FIP UM. Strategi yang dapat ditempuh adalah kelas dibagi ke dalam beberapa kelompok dan masing-masing kelompok itu ditugaskan melakukan riset sederhana dalam merumuskan permasalahan-permasalahan yang ada di lembaga pendidikan untuk kemudian dievaluasi dan didiskusikan kembali di dalam kelas dan dicarikan solusi dari permasalahan tersebut melalui model bermain peran (role playing). Melalui Model pembelajaran bermaian peran berbasis masalah mahasiswa dapat memperagakan atau berperan sebagai supervisor dan guru yang merupakan komponen utama dalam kegiatan supervisi pengajaran.

Mahasiswa diberikan kebebasan untuk menganalisis permasalahan yang berkaitan dengan pelaksanaan supervisi pengajaran yang selanjutnya dibuat alternatif pemecahan masalah melalui pembuatan produk video bermain peran yang dapat dijadikan bahan kajian diskusi dalam sistem perkuliahan berbasis online melalui SIPEJAR. Pemanfaatan SIPEJAR merupakan sebagai salah satu ciri pembelajaran dengan model blended learning yang memadukan sistem online dan offline.

Pemanfaatan SIPEJAR sebagai sistem pembelajaran dalam jaringan penting dilakukan untuk memudahkan mahasiswa dan dosen dalam proses pembelajaran. Berdasarkan latar belakang tersebut, maka tujuan pengembangan inovasi belajar ini adalah mengembangkan video bahan ajar pada perkuliahan blended learning supervisi pengajaran.melalui model pembelajaran Problem Based Role Playing (PBRP).

\section{METODE}

Penelitian ini menggunakan metode penelitian pengembangan yang bersifat analisis kebutuhan. Menurut Borg and Gall (Sugiyono, 2019) dalam bidang pendidikan. penelitian dan Pengembangan (research and development) merupakan metode penelitian yang digunakan untuk mengembangkan atau memvalidasi produk-produk yang digunakan dalam pendidikan dan pembelajaran. Penelitian pengembangan ini mengacu kepada langkah-langkah pengembangan menurut (Walter Borg \& Meredith Gall, 1995), yang dimodifikasi dan disederhanakan menjadi: (1) analisis permasalahan; (2) 
pengembangan produk (draf I); (3) uji produk (draf I); (4) revisi produk (draf I); (5) validasi produk (draf II); dan (6) produk akhir.

Rancangan pengembangan PBRP ini disusun oleh peneliti secara sistematis tahapan demi tahapan dalam bentuk alur kerja dalam rangka memudahkan peneliti untuk melaksanakan proses penelitian pengembangan. Kegiatan tahapan tersebut mulai dari studi pendahuluan sampai dengan tersusunnya produk akhir pengembangan, yakni dalam penelitian ini adalah video bahan ajar blended learning matakuliah supervisi pengajaran dengan model pembelajaran PBRP. Adapun rancangan pengembangan dapat dilihat pada pada Gambar 1.

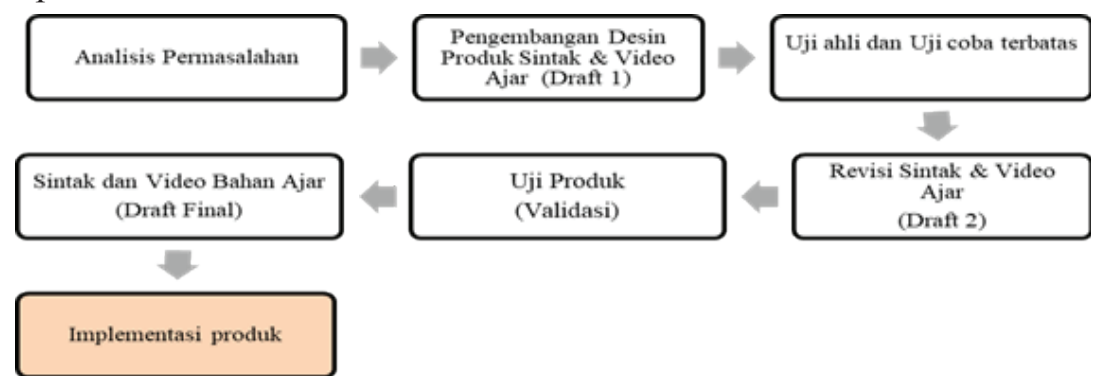

Instrumen yang digunakan dalam penelitian ini adalah angket dan lembar validasi. Angket digunakan untuk mengidentifikasi permasalahan pembelajaran matakuliah supervisi pengajaran dengan model PBRP. Lembar validasi produk digunakan untuk menilai kelayakan produk yang dihasilkan. Indikator kelayakan video pembelajaran menyangkut komponen kelayakan isi sesuai dengan materi perkuliahan supervisi pengajaran, komponen bermain peran yang dimuat dalam video serta komponen kualitas video yang dihasilkan.

Proses analisis data yang digunakan dalam penelitian pengembangan ini adalah melalui deskriptif kuantitatif. Data-data yang dihasilkan dari sebaran instrumen angket mahasiswa dianalisis menggunakan formula stanfive (Gunawan, 2013). Rumus stanfive ini digunakan untuk dapat mendeskripsikan permasalahan pembelajaran seperti ditampilkan pada tabel 1. Kategori disetiap item pernyataan digunakan untuk menggambarkan setiap item pernyataan melalui rerata nilai setiap pernyataan yang ditentukan dengan jumlah nilai item dibagi jumlah responden.

Tabel 1 Rumus Stanfive untuk Deskripsi Permasalahan Pembelajaran

\begin{tabular}{ccc}
\hline No & Formula Rumus & Kategori \\
\hline 1 & $(\overline{\mathrm{X}}+1,5 \mathrm{DS})<\mathrm{X}$ & Sangat baik \\
2 & $(\overline{\mathrm{X}}+0,5 \mathrm{DS})<\mathrm{X}<(\overline{\mathrm{X}}+1,5 \mathrm{DS})$ & Baik \\
3 & $(\overline{\mathrm{X}}-0,5 \mathrm{DS})<\mathrm{X}<(\overline{\mathrm{X}}+0,5 \mathrm{DS})$ & Cukup baik \\
4 & $(\overline{\mathrm{X}}-1,5 \mathrm{DS})<\mathrm{X}<(\overline{\mathrm{X}}-0,5 \mathrm{DS})$ & Kurang baik \\
5 & $\mathrm{X}<(\overline{\mathrm{X}}-1,5 \mathrm{DS})$ & Tidak baik \\
\hline
\end{tabular}

Sumber: (Wiyono, \& Sunarni., 2009)

Selanjutnya dilakukan analisis untuk melihat rerata nilai setiap item pernyataan dibandingkan dengan rerata nilai semua item pernyataan menggunakan ketentuan: (1) jika rerata nilai item pernyataan $>$ rerata nilai semua item pernyataan, maka berarti item pernyataan tersebut termasuk dalam kategori tinggi (T); dan (2) jika rerata nilai item pernyataan $\leq$ rerata nilai semua item pernyataan, maka berarti item pernyataan tersebut termasuk dalam kategori rendah (R). Setiap item pernyataan yang berkategori tinggi merupakan jabaran indikator variabel yang harus dipertahankan, sedangkan butir soal yang berkategori rendah merupakan jabaran indikator variabel yang harus ditingkatkan. Item pernyataan yang termasuk dalam kategori rendah merupakan indikasi permasalahan pembelajaran yang dilaksanakan.

Analisis yang digunakan dalam penelitian ini untuk menilai produk yang dikembangkan layak digunakan atau tidak adalah dengan analisis deskriptif melalui formula stanfive (Gunawan, 2013). Melalui rumus stanfive digunakan untuk menentukan kelayakan produk seperti ditampilkan pada tabel 2 . 
Tabel 2 Rumus Stanfive untuk Menentukan Kelayakan Produk

\begin{tabular}{ccc}
\hline No & Formula Rumus & Kategori \\
\hline 1 & $(\overline{\mathrm{X}}+1,5 \mathrm{DS})<\mathrm{X}$ & Sangat layak \\
2 & $(\overline{\mathrm{X}}+0,5 \mathrm{DS})<\mathrm{X}<(\overline{\mathrm{X}}+1,5 \mathrm{DS})$ & Layak \\
3 & $(\overline{\mathrm{X}}-0,5 \mathrm{DS})<\mathrm{X}<(\overline{\mathrm{X}}+0,5 \mathrm{DS})$ & Cukup layak \\
4 & $(\overline{\mathrm{X}}-1,5 \mathrm{DS})<\mathrm{X}<(\overline{\mathrm{X}}-0,5 \mathrm{DS})$ & Kurang layak \\
5 & $\mathrm{X}<(\overline{\mathrm{X}}-1,5 \mathrm{DS})$ & Tidak layak \\
\hline
\end{tabular}

Sumber: (Wiyono, \& Sunarni., 2009)

\section{HASIL}

\section{Video Bahan Ajar Digital}

Hasil penelitian pengembangan ini adalah berupa delapan video teknik supervisi pengajaran yang dihasilkan dari implementasi PBRP. Delapan video bahan ajar bermain peran (role playing) kemudian diuji oleh para ahli (expert) yang terdiri dari dua ahli yaitu: ahli pertama menilai tentang komponen kelayakan isi sesuai dengan materi perkuliahan supervisi pengajaran, komponen bermain peran yang dimuat dalam video, dan ahli dua menilai tentang komponen kualitas video. Video draft 1 tersebut sebagai hasil produk draft 1 untuk dapat dinilai oleh ahli. Selanjutnya setelah proses penilaian oleh ahli dan memberikan masukan-masukan tentang video pembelajaran supervisi pengajaran, maka dilakukan revisi atau perbaikan video sesuai dengan saran ahli. Adapun video hasil revisi ini kemudian dijadikan sebagai video produk draft final.

Setelah dihasilkan produk video revisi sebagai draft 2, maka selanjutnya dilakukan analisis melalui angket validasi instrument media terhadap video bahan ajar mata kuliah supervisi pengajaran dari para ahli untuk 8 video masing-masing terdiri dari 20 item pertanyaan dengan skala 4, dengan nilai minimal $8 \times 20 \times 1=160$ dan nilai maksimal 8x20x4=640. Hasil validasi terhadap produk video draft 2 menunjukan bahwa video produk bermain peran untuk pembelajaran supervisi pengajaran dinyatakan BAIK oleh ahli pertama dan ahli kedua. Hasil validasi dapat dilihat pada tabel 3 berikut:

Tabel 3 Validasi Ahli untuk Keseluruhan Video Bahan Ajar Draf 2

\begin{tabular}{ccccc}
\hline \multirow{2}{*}{ No } & \multirow{2}{*}{ Arti } & \multirow{2}{*}{ Range } & \multicolumn{2}{c}{ Expert } \\
\cline { 4 - 5 } & & $160-280$ & 0 & 0 \\
\hline 1 & Tidak Baik & $281-400$ & 0 & 0 \\
2 & Kurang Baik & $401-520$ & 0 & 0 \\
3 & Cukup Baik & $521-640$ & 2 & 100 \\
4 & Baik & & 2 & 100 \\
\hline
\end{tabular}

Berdasarkan hasil penilaian ahli terhadap draft 2 tentang video bermain peran pada matakuliah supervisi pengajaran, maka hasil video draft 2 dinyatakan sebagai hasil akhir/hasil final. Sehingga video draft 2 selanjutnya dilakukan uji coba kepada mahasiswa melalui instrument angket kepada mahasiswa. Uji coba dilakukan kepada 40 mahasiswa program studi administrasi pendidikan yang masing-masing berjumlah 20 item pertanyaan dengan skala 4 dengan nilai minimal 8x20x1= 160 dan nilai maksimal $8 \times 20 \times 4=640$. Hasil isian instrument terhadap produk video draft 2 menunjukan bahwa video produk bermain peran untuk pembelajaran supervisi pengajaran dinyatakan BAIK oleh mahasiswa. Hasil isian instrumen dapat dilihat pada tabel 4.

Selain menggunakan instrument tersebut, selanjutnya dilakukan analisis data uji coba dari setiap video bahan ajar bermain peran untuk mata kuliah supervisi pengajaran yang terdiri dari 8 video dengan jumlah item pertanyaan sebanyak 20 item dengan skala 4, menghasilkan nilai minimal 20x1=20 dan nilai maksimal $20 \times 4=80$ serta interval 15 . Adapun hasil isian intrumen dari 8 video bermain peran sebagai bahan ajar mata kuliah supervisi pengajaran didapatkan data bahwa setiap video dinyatakan 
BAIK oleh mahasiswa. Hasil uji coba setiap video dapat dilihat dalam tabel 5.

Tabel 4 Hasil Uji Coba Seluruh Video Final (Video 1-Video 8) kepada Mahasiswa.

\begin{tabular}{clccc}
\hline No & \multicolumn{1}{c}{ Arti } & Range & Frekuensi & \% \\
\hline 1 & Tidak baik/sesuai/jelas/komunikatif & $160-280$ & 0 & 0 \\
2 & Kurang baik/sesuai/jelas/komunikatif & $281-400$ & 0 & 0 \\
3 & Cukup baik/sesuai/jelas/komunikatif & $401-520$ & 0 & 0 \\
4 & Baik/sesuai/jelas/komunikatif & $521-640$ & 40 & 100 \\
& Jumlah & & 40 & 100 \\
\hline
\end{tabular}

Tabel 5 Hasil Uji Coba setiap Video kepada Mahasiswwa

\begin{tabular}{|c|c|c|c|c|c|}
\hline \multirow{3}{*}{ No } & \multirow{3}{*}{ Video Final Bahan Ajar } & \multicolumn{4}{|c|}{ Range-Arti - Frekuensi } \\
\hline & & $20-34$ & $35-49$ & $50-64$ & $65-80$ \\
\hline & & $\begin{array}{l}\text { Tidak } \\
\text { Baik }\end{array}$ & $\begin{array}{c}\text { Kurang } \\
\text { Baik }\end{array}$ & $\begin{array}{l}\text { Cukup } \\
\text { Baik }\end{array}$ & Baik \\
\hline 1 & $\begin{array}{l}\text { Video bermain peran tentang teknik supervisi klinis } \\
\text { dengan pendekatan kolaboratif }\end{array}$ & 0 & 0 & 0 & 72 \\
\hline 2 & $\begin{array}{l}\text { Video bermain peran tentang teknik supervisi individual } \\
\text { melalui percakapan pribadi }\end{array}$ & 0 & 0 & 0 & 72 \\
\hline 3 & $\begin{array}{l}\text { Video bermain peran tentang teknik supervisi kelompok } \\
\text { melalui MGMP }\end{array}$ & 0 & 0 & 0 & 72 \\
\hline 4 & $\begin{array}{l}\text { Video bermain peran tentang teknik supervisi individu } \\
\text { melalui orentasi guru baru }\end{array}$ & 0 & 0 & 0 & 72 \\
\hline 5 & $\begin{array}{l}\text { Video bermain peran tentang teknik supervisi kelompok } \\
\text { melalui rapat guru }\end{array}$ & 0 & 0 & 0 & 72 \\
\hline 6 & $\begin{array}{l}\text { Video bermain peran tentang teknik supervisi individu } \\
\text { melalui observasi kelas dengan pendekatan direktif }\end{array}$ & 0 & 0 & 0 & 72 \\
\hline 7 & $\begin{array}{l}\text { Video bermain peran tentang teknik supervisi individu } \\
\text { melalu teknik menilai diri sendiri (self evaluation) }\end{array}$ & 0 & 0 & 0 & 72 \\
\hline 8 & $\begin{array}{l}\text { Video bermain peran tentang teknik supervisi individu } \\
\text { melalui demonstrasi mengajar }\end{array}$ & 0 & 0 & 0 & 72 \\
\hline
\end{tabular}

Hasil analisis uji beda berdasarkan jenis kelamin antara mahasiswa laki-laki dan perempuan tentang tanggapan mengenai produk video bahan ajar melalui bermain peran pada mata kuliah supervisi pengajaran dengan analisis uji beda menggunakan kolmogorov-smirnov test; asymp.sig (2-tailed) = 1,$000 ; \mathrm{df}=5 \%$. Hasil asymp.sig. $(2$-tailed $)>5 \%$, maka Ho diterima yang berarti tidak ada perbedaan antara mahasiswa laki-laki dan perempuan dalam menilai produk video bahan ajar ajar melalui bermain peran pada mata kuliah supervisi pengajaran. Berdasarkan hasil analisis data uji coba dan masukan yang sudah BAIK, maka produk final yang berupa delapan video bahan ajar melalui bermain peran untuk mata kuliah supervisi pengajaran tidak direvisi lagi.

\section{Sintak Model Problem Based Role Playing (PBRP)}

Hasil pengembangan terhadap model Problem Based Role Playing (PBRP) pada mata kuliah supervisi pengajaran sebagai draft sintak PBRP untuk dijadikan bahan penilaian oleh para ahli. Adapun draft sintak implementasi PBRP pada perkuliahan supervisi pengajaran disajikan dalam tabel 6 .

Tabel 6 Draft.1 Sintak PBRP

\begin{tabular}{cll}
\hline Tahap & \multicolumn{1}{c}{ Kegiatan Mahasiswa } & Pertemuan \\
\hline & $\bullet$ & Mahasiswa mendengarkan penjelasan dosen tentang CPMK Supervisi \\
Fase 1 & $\begin{array}{l}\text { Pengajaran, memberikan kontrak perkuliahan dan penjelasan singkat } \\
\text { tentang perkuliahan supervisi pengajaran }\end{array}$ & 1 \\
Preparing & & Mahasiswa mengunduh RPS dan SAP yang disediakan dosen
\end{tabular}




\begin{tabular}{|c|c|c|}
\hline Tahap & Kegiatan Mahasiswa & Pertemuan \\
\hline $\begin{array}{c}\text { Fase } 2 \\
\text { Creating Grup }\end{array}$ & $\begin{array}{l}\text { - Mahasiswa membentuk kelompok-kelompok secara proporsional } \\
\text { - Mahasiswa berdiskusi dan menentukan tugas masing-masing setiap } \\
\text { anggota kelompok }\end{array}$ & 2 \\
\hline $\begin{array}{l}\text { Fase } 3 \\
\text { Problems } \\
\text { Analyse }\end{array}$ & $\begin{array}{l}\text { - Mahasiswa melakukan analisis lapangan tentang implementasi supervisi } \\
\text { pengajaran } \\
\text { Mahasiswa mengidentifikasi permasalahan dan menganalisis temuan } \\
\text { serta merancang pemecahan masalah }\end{array}$ & 3 \\
\hline $\begin{array}{l}\text { Fase } 4 \\
\text { Problems } \\
\text { Finding and } \\
\text { Problems } \\
\text { Solving }\end{array}$ & $\begin{array}{l}\text { - Mahasiswa menentukan satu focus permasalahan } \\
\text { - Mahasiswa merancang alternative pemecahan masalah sesuai dengan } \\
\text { focus permasalahan yang dipilih }\end{array}$ & 4 \\
\hline $\begin{array}{l}\text { Fase } 5 \\
\text { Division of } \\
\quad \text { roles }\end{array}$ & $\begin{array}{l}\text { Mahasiswa melakukan pembagian peran untuk setiap anggota kelompok } \\
\text { dan menentukan tempat untuk pembuatan produk pembelajaran bermain } \\
\text { peran } \\
\text { - Mahasiswa membuat video bermain peran sesuai dengan permasalahan } \\
\text { yang dipilih }\end{array}$ & 5 \\
\hline $\begin{array}{l}\text { Fase } 6 \\
\text { Discussion and } \\
\text { evaluation }\end{array}$ & $\begin{array}{l}\text { Mahasiswa menyajikan produk video bermain peran sesuai masing- } \\
\text { masing kelompok yang telah diunggah kedalam SIPEJAR dosen } \\
\text { pengampu mata kuliah } \\
\text { Mahasiswa/kelompok lain menanggapi video yang diunggah kelompok } \\
\text { lainnya }\end{array}$ & $6-14$ \\
\hline $\begin{array}{l}\text { Fase } 7 \\
\text { Share } \\
\text { experience and } \\
\text { conclusions }\end{array}$ & $\begin{array}{l}\text { Mahasiswa diberikan kesempatan untuk saling bertukar pengalaman } \\
\text { selama memainkan peran dan memberikan kesimpulan tentang materi } \\
\text { sesuai dengan tema yang dipilih. }\end{array}$ & 15 \\
\hline & - UAS & 16 \\
\hline
\end{tabular}

Langkah selanjutnya setelah mendapat masukan dari pada ahli, maka draft 1 tentang sintak implementasi PBRP pada perkuliahan supervisi pengajaran dilakukan revisi. Setelah proses revisi selanjutnya dilakukan analisis melalui angket validasi instrument desain pembelajaran (terlampir) terhadap draft.1. Adapun hasil validasi dari para ahli tentang draft.1 sintak model PBRP disajikan dalam tabel 7 berikut ini:

Tabel 7 Validasi Ahli untuk Sintak Draf 1

\begin{tabular}{clccc}
\hline \multirow{2}{*}{ No } & \multicolumn{1}{c}{ Aspek Penilaian } & \multicolumn{2}{c}{ Skor } & \multirow{2}{*}{ Total } \\
\cline { 3 - 4 } & & Expert 1 & Expert 2 & \\
\hline 1 & Identifikasi tujuan umum pembelajaran & 4 & 4 & 8 \\
2 & Analisis pembelajaran & 4 & 4 & 8 \\
3 & Identifikasi perilaku dan karakteristik pebelajar & 4 & 7 \\
4 & Rumusan tujuan kinerja & 4 & 4 & 8 \\
5 & Rumusan kriteria acuan penilaian & 4 & 4 & 8 \\
6 & Pengembangan strategi pembelajaran & 4 & 4 & 8 \\
7 & Pengembangan dan seleksi materi & 4 & 4 & 8 \\
8 & Rancangan bahan pembelajaran & 4 & 4 & 8 \\
9 & Pengembangan dan pelaksanaan evaluasi formatif & 3 & 4 & 7 \\
10 & Pengembangan dan pelaksanaan evaluasi sumatif & 39 & 39 & 78 \\
\end{tabular}

Penilaian yang dilakukan oleh ahli menggunakan instrument dengan jumlah pertanyaan sebanyak 10 item dengan skala 4 , diperoleh nilai minimal $1 \times 10=10$ dan nilai maksimal $4 \times 10=40$ dengan ratarata 7,5. Tabel 8 dapat dilihat bahwa penilaian yang dilakukan oleh ahli 1 dan ahli 2 mendapat skor penilaian 39 termasuk dalam kategori rata-rata 36-40 yang berarti produk revisi draft.1 dinyatakan baik. 
Sedangkan jika dilakukan penghitungan secara bersamaan dengan menjumlahkan skor ahli 1 dan ahli 2 dengan 10 item pertanyaan skala 4 , maka diperoleh nilai minimal 1x10x2=20 dan maksimal 4x10x2 $=80$ serta range 15 . Dari hasil penghitungan yang dilakukan oleh kedua ahli didapatkan skor 78 yang termasuk kedalam rata-rata 65-80 atau diartikan bahwa revisi produk drfa.1 dinyatakan baik. Dari hasil validasi yang dilakukan oleh kedua ahli baik dilihat dari penghitungan individu ataupun penggabungan skore, maka dapat disimpulkan bahwa hasil revisi draft. 1 tentang sintak PBRP pada matakuliah supervisi pengajaran dinyatakan BAIK.

Tabel 8 Range Penilaian ahli draft.1

\begin{tabular}{cccc}
\hline No & Arti & $\begin{array}{c}\text { Range } \\
\text { (Tiap Ahli) }\end{array}$ & $\begin{array}{c}\text { Range } \\
\text { (Bersamaan) }\end{array}$ \\
\hline 1 & Tidak Baik & $10-17$ & $20-34$ \\
2 & Kurang Baik & $18-25$ & $35-49$ \\
3 & Cukup Baik & $26-33$ & $50-64$ \\
4 & Baik & $34-40$ & $65-80$ \\
\hline
\end{tabular}

Hasil revisi draft.1 kemudian dijadikan sebagai produk draft.2 Final sintak PBRP. Adapun draft.2 Final sintak implementasi PBRP pada matakuliah supervisi pengajaran dapat dilihat pada tabel 9 berikut:

Tabel 9 Draft.2 Final Sintak Implementasi PBRP

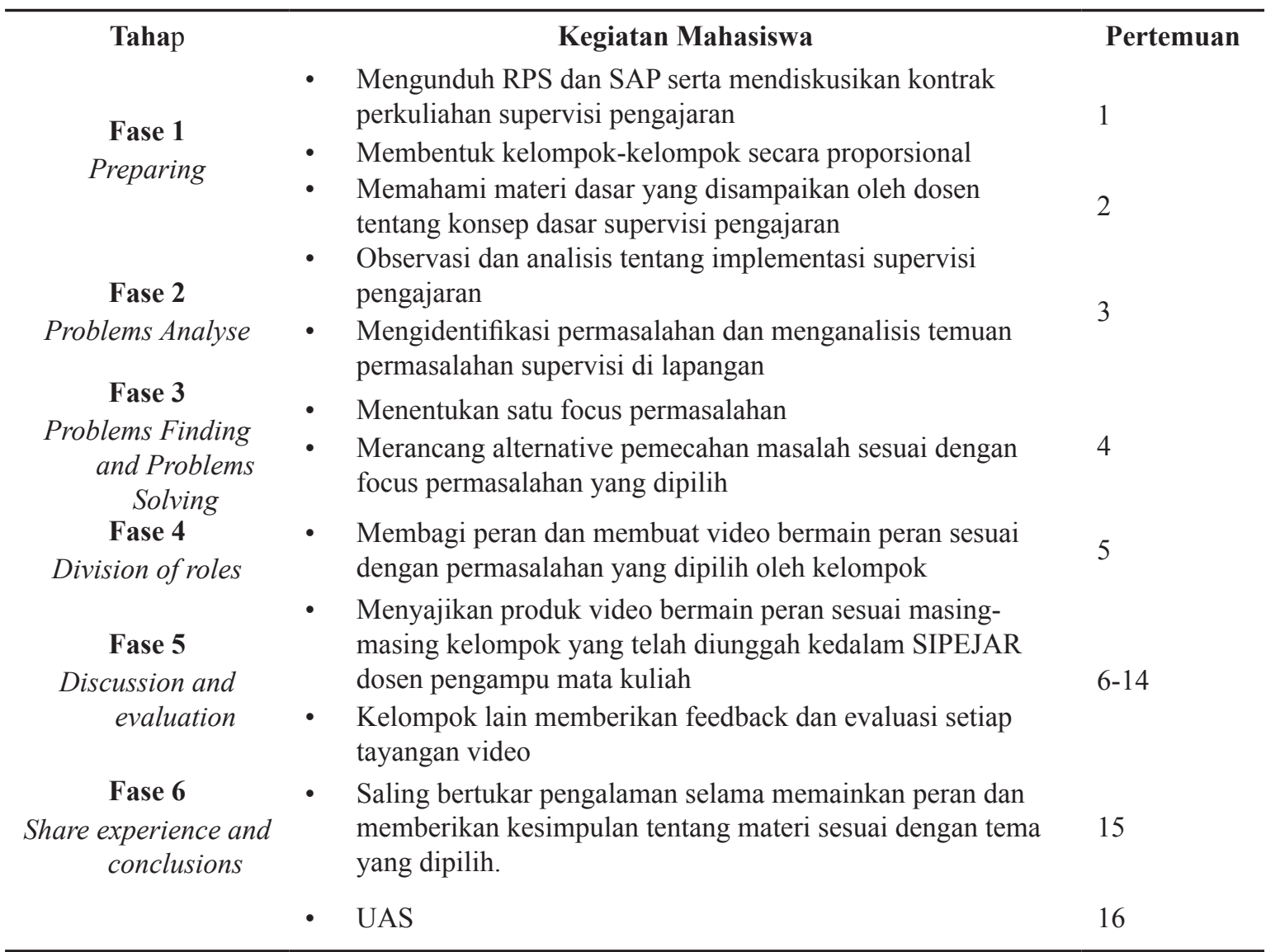

\section{PEMBAHASAN}

\section{Model Pembelajaran Aktif dalam PBRP}

Pada penelitian pengembangan yang menghasilkan produk ini berupa model pembelajaran PBRP, di dalamnya masih terdapat dua model. Mengapa demikian, sebab hal tersebut merupakan suatu hal yang saling membaur dan bersinergi untuk menghasilkan iklim pembelajaran yang kondusif. Dua model pembelajaran yang ada di dalam PBRP adalah (1) model pembelajaran Problem Based Learning, dan (2) model role playing. Terdapat dua hal dalam Pendekatan model pembelajaran berbasis masalah 
(PBM)/Problem Based Learning (PBL) yakni, penggunaan inteligensi dari dalam diri individu yang berada dalam sebuah kelompok orang, atau lingkungan untuk memecahkan masalah yang bermakna, relevan, dan kontekstual. Pembelajaran berbasis masalah adalah seperangkat model mengajar yang menggunakan masalah sebagai fokus untuk mengembangkan ketrampilan pemecahan masalah, materi, dan pengaturan diri (Nurdyansyah dan Eni Fariyatul Fahyuni, 2016). Pelajaran dan pembelajaran berbasis masalah memiliki tiga karakteristik yang digambarkan dalam (Gijbels, Dochy, Van den Bossche, \& Segers, 2005) yakni: Pertama, pelajaran berawal dari masalah dan memecahkan masalah adalah fokus pelajarannya. Kedua, siswa bertanggung jawab untuk menyusun strategi dan memecahkan masalah. Ketiga, guru menuntun upaya siswa dengan mengajukan pertanyaan dan memberi dukungan pengajaran lain saat siswa berusaha memecahkan masalah. Studi kasus Pembelajaran Berbasis Masalah (PBM), meliputi: 1) penyajian masalah; 2) menggerakkan inkuiri; 3) langkah-langkah PBM, yaitu analisis inisial, mengangkat isu-isu belajar; literasi kemandirian dan kolaborasi pemecahan masalah, integrasi pengetahuan baru, penyajian solusi dan evaluasi.

Pembelajaran bermain peran (role playing) merupakan pembelajaran efektif yang melibatkan mahasiswa untuk dapat berperan aktif melibatkan dirinya untuk berperan sesuai dengan tema-tema pembelajaran (Anggraeni, 2018). Penggunaan model pembelajaran role playing akan dapat menciptakan suasana baru yang tidak membosankan di kelas karena mahasiswa akan secara aktif bermain peran, sementara itu dosen dapat menganalisis perilaku mahasiswa dalam setiap kesempatan pembelajaran bermain peran (Sari, 2018). Model pembelejaran role playing dapat dikelompokkan menjadi dua dimensi. Dimensi pertama yaitu interaktivitas dosen, dimensi ini berkaitan dengan tingkat keterlibatan kelas, di mana pengajaran sepenuhnya delakukan secara interaktif dan melibatkan partisipasi yang tinggi bagi mahasiswa. Landasan teoritis untuk ini didasarkan pada (Kolb, 2007), yang menempatkan interaksi dan aktivitas sebagai elemen dasar dalam proses pembelajaran. Dimensi kedua adalah 'berpikir' (kognitif) vs perasaan (afektif) (Errington, 1997). Pembelajaran dengan model role playing menjadi salah satu model pembelajaran aktif yang memberikan kesempatan kepada siswa untuk aktif dalam kegiatan pembelajaran dengan cara memberikan kesempatan untuk memerankan subjek-subjek yang menjadi bahan bahasan atau materi pembelajaran di dalam kelas (Setiawati, 2016). Pembelajaran dengan model role playing dapat memberikan manfaat bagi mahasiswa untuk 1) mengeksplorasi perasaan mahasiswa, 2) mentransfer dan mewujudkan mengenai perilaku, nilai, dan persepsi mahasiswa, 3) mengembangkan keterampilan pemecahan masalah dan tingkah laku, 4) mengeksplorasi materi pembelajaran dengan cara yang berbeda (Sinanglingtyas, 2013). Dalam pembelajaran role playing terdapat empat aspek umum yang digunakan diantaranya sintak, sistem sosial, tugas/peran guru, dan pengaruh model (Mawardi, 2018). Sintak pada model role playing meliputi: 1) pemanasan, 2) memilih pemain, 3) menata atau menentukan tempat 4) memainkan peran, 5) diskusi dan evaluasi, 6) berbagi pengalaman dan kesimpulan. Sistem sosial merupakan relasi antara dosen dan mahasiswa, peran dosen memiliki tanggung jawab untuk menjelaskan, membimbing mahasiswa dalam aktivitas bermain peran.

Model pembelajaran melalui Problem Based Role Playing (PBRP) merupakan model pengembangan yang memadukan dua model pembelajaran aktif yaitu model problem based dan role playing. Melalui pengembangan ini diharapkan dapat meningkatkan kualitas dan efektifitas pembelajaran mahasiswa. Melalui PBRP ini berusaha untuk menciptakan proses pembelajaran aktif yang dapat melatih mahasiswa untuk berfikir menganalisis permasalahan kemudian memecahkan masalah tersebut melalui kajian teoretis dan dipraktekan dalam bentuk bermain peran. Dengan PBRP ini maka mahasiswa bukan hanya paham secara teori namun dilatih untuk terlibat langsung sebagai subjek dalam memecahkan masalah tersebut, dengan begitu mahasiswa akan medapatkan pengalaman dan merasakan seperti apa yang menjadi bahasan dalam permasalahan yang dikaji.

Menurut (Yehuda Baruch, 2006) melalui metode pembelajaran bermain peran, maka mahasiswa menjadi terlibat dan menjadi bagian dari materi-materi yang menjadi kajian. Partisipasi aktif melalui bermain peran dalam pembelajaran menunjukan hasil yang efektif dalam proses pembelajaran terutama untuk membangun pengalaman belajar mahasiswa. Melalui penelitiannya Baruch menjelaskan bahwa model ini menggeabungkan beberapa dimensi yang melibatkan antara fikiran dan perasaan. Secara umum keempat dimensi ini dapat dilihat dalam bentuk kuadran seperti gambar 2.3 di bawah ini (Yehuda 
Baruch, 2006): Dalam Implementasi model PBRP memerlukan pedoman yang dapat digunakan dalam kegiatan pembelajaran di kelas untuk dapat mengkonsep sistem pembelajaran yang otentik yang memerlukan pemikiran yang kritis, kreatif dan handal dalam memecahkan permasalahan. Pedoman penerapan PBRP dibagi dalam dua kategori yaitu pedoman komprehensif dan aktivitas proses.

Pedoman komprehensif merupakan pedoman umum yang digunakan sebagai dasar dan diimplementasikan dalam keseluruhan proses, sedangkan aktivitas proses terbatas pada fase tertentu dari proses pemecahan masalah dan bermain peran. Pandangan dasar yang pada metode PBRP ini adalah bahwa lingkungan pembelajaran yang ideal adalah pembelajaran yang dapat menciptakan kerja sama antar mahasiswa yang dapat memancing dan menumbuhkan sikap berfikir kritis, mampu menganalisis permasalahan dan mencari pemecahan atas permasalahan dengan cara mengintegrasikan antara penguasaan materi konseptual dengan pengalaman nyata melalui bermain peran secara langsung di dalam kelas yang dikembangkan dengan perpaduan blended learning yaitu memadukan media online melalui video-video praktek bermain peran dan memecahkan masalah dan juga melalui pertemuan tatap muka di kelas.

\section{Kelayakan PBRP (Problem Based Role Playing) Sebagai Model Pembelajajaran Perkuliahan}

Bilamana membahas dan mengulas terkait dengan kelayakan PBRP, tentu dalam hasil penelitian telah dinyatakan bahwsanya PBRP memenuhi berbagai syarat melalui uji validasi ahli. Namun bilamana dianalisis secara mendalam tentu dalam konteks pembahasan artikel ini, tim peneliti juga akan menyajikan kelayakan dari PBRP ini, bila di dasarkan dengan theoretical based terkait kriteria model pembelajaran yang baik. Maka dari itu, telaah kelayakan pada pembahasan ini akan disandarkan pada satu hal utama, yakni bahan ajar dan model pembelajaran PBRP ini sendiri, yang akan dibahas mengenai kelayakannya dari teori menurut (Afandi, Chamalah, \& Puspita Wardani, 2013) bahwasanya sebuah model pembelajaran yang baik ialah sebuah model pembelajaran yang memuat beberapa hal yakni (1) membangkitkan rasa ingin tahu, (2) membentuk optimisme positif pembelajaran, (3) kreativitas pebelajar yang akan tumbuh, (4) pengaplikasian yang efektif. Pada model pembelajaran PBRP (Problem Based Role Playing) dimana, didalamnya mengandung unsur pembelajaran PBL (problem based learning) dan juga unsur pembelajaran role playing bilamana dikaitkan dengan poin pertama, terkait dengan membangkitkan rasa ingin tahu tentu hal tersebut sangat berhubungan erat. Mengapa demikian, sebab pembangkitan sebuah rasa ingin tahu merupakan suatu hal yang menjadi output dari problem based learning.

Karena pada dasarnya problem based learning sendiri merupakan suatu model pembelajaran yang mengacu pada penyelesaian masalah bersifat faktual (Burden, P. R \& Byrd, 2013). Obyek masalah faktual itulah yang menjadi stimulus seorang peserta didik untuk mempelajari dan menyelesaikan suatu proses pembelajaran secara optimal dengan penuh gairah. Gagasan tim peneliti tersebut senada dengan gagasan dari (Zadina, 2014) bahwasanya, stimulus terbaik selain reward and punishment untuk kelangsungan proses pembelajaran, ialah berupa sajian proses pembelajaran dengan pemberian masalah faktual sebagai obyek yang harus diselesaikan siswa, sebab hal tersebut akan membentuk mindset dikalangan siswa atau pebelajar, bahwa suatu hal yang dipelajarinya memang benar-benar berfungsi dalam kehidupan nyata. Jadi, dapat ditarik benang merahnya, secara sederhanya bahwasanya karena siswa telah mengetahui nilai pragmatik dari pengalaman belajar demikian ini, akan membuat siswa menjadi bersemangat karena apa yang dipelajarinya, sudah terbukti benar-benar terpakai dalam kehidupannya sehari-hari, sehingga rasa ingin tahunya semakin tinggi. Setelah dibahas mengenai unsur Problem Based Learning yang ada, maka masih terdapat unsur role playing dalam pembelajaran PBRP. Unsur role playing bilamana dikorelasikan dengan syarat pembelajaran yang optimal pada poin pertama, yakni membangkitkan rasa ingin tahu, tentu menurut tim peneliti dirasa memiliki hubungan yang kuat didalamnya. Hal ini tentunya didukung oleh hasil penelitian dari (Phelan, 2015) bahwa suatu pembelajaran yang sifatnya bermain peran akan bermuara pada integrasi dan asimilasi pengetahuan baru secara efisien, sebab pembelajaran yang mengandung unsur bermain peran akan menimbulkan persepsi ingin tahu yang tinggi dari pebelajar. Persepsi ingin tahu yang tinggi tersebut, timbul karena seorang 
pebelajar berkeinginan untuk mengetahui seperti apa rasanya bila memerankan suatu karakter atau peran dalam konteks pembelajaran. Pada konteks ini, tentu dalam supervise pengajaran terdapat dua karakter atau pemeran, yakni (1) guru sebagai supervisee, dan (2) supervisor. Maka dari itulah, seorang pebelajar atau dalam konteks ini mahasiswa, akan senantiasa berkeinginan tinggi dalam mengkaji mata kuliah supervise pengajaran, sebab persepsi dari diri pebelajar atau mahasiswa ialah ingin mengetahui terkait bagaimana proses supervise akademik, serta bagaimana rasanya menjadi seorang supervisor. Dengan demikian, model pembelajaran ini tidak hanya menarik rasa ingin tahu yang tinggi, namun sekaligus memberikan pengalaman belajar berupa learning by doing the experience.

Setelah dibahas secara kompleks mengenai poin pertama, maka akan dibahas terkait dengan poin kedua yang ada dalam paparan theoretical based, yakni pembelajaran yang baik adalah pembelajaran yang dapat membangkitkan optimisme diri pebelajar. Optimisme belajar dengan rasa ingin tahu merupakan suatu hal yang sama, namun berbeda jalur realisasi dalam praktiknya. Bilamana rasa ingin tahu merupakan bagian dari motivasi intrinsic yang direalisasikan melalui gairah belajar yang tinggi, maka bila optimisme belajar realisasi praktiknya dimanifestasikan dalam pengerjaan tugas yang optimal, serta selalu memenuhi standar kriteria yang ada. Senada dengan ungkapan dari (Winkel, 1989) bahwa optimisme belajar adalah suatu proses dalam psikis seseorang Ketika belajar hal baru, yang direpresentasikan dengan obsesi untuk mengerjakan berbagai hal yang sifatnya tugas pembelajaran secara (1) kompleks, (2) tertata, (3) sistemik. Bilamana ditinjau menengai PBRP, pada poin ini tentu hal tersebut merujuk pada kriteria dari ciri-ciri optimisme pebelajar dalam sebuah proses belajar dan pembelajaran. Mengapa dapat digeneralisasi demikian, sebab pembelajaran dari PBRP ini cenderung berfokus pada berbagai fase yang cukup kompleks prosesnya pada setiap fase. Kompleksitas perencanaan proses itulah yang menyebabkan sebuah pembelajaran menggunakan PBRP mengandung optimisme belajar dari kalangan pebelajar didalamnya. Sistemasi melalui beberapa fase dari preparing hingga tahap akhir itulah yang menjadi stimulus tercipatanya tugas dari pebelajar menjadi kompleks dan memenuhi standar kriteria yang ada. Dapat disimpulkan demikian, karena pada setiap tahap atau fase pembelajaran terdapat kegiatan yang mengarah pada pengawasan dan control pembelajaran secara optimal, atau bisa juga disebut jika setiap tahap pada proses pembelajaran di dalam PBRP mengandung total quality control. Diungkapkan oleh (Sallis, 2014) bahwa total quality control adalah tool conceptual yang digunakan untuk menciptakan suatu output yang sifatnya melebihi standar penilaian. Oleh karena itu, dapat diasumsikan bahwa PBRP sebagai pembelajaran memenuhi kelayakannya dalam mengeksternalisasi optimisme belajar di kelangan pebelajaranya, sebab melalui total quality control dalam setiap fase pembelajarannya, PBRP dapat mengaktualisasikan hal tersebut secara optimal dan kompleks.

Pada poin ketiga sendiri yakni berkenaan dengan memacu kreativitas dari pebelajar. Hal tersebut secara rasional bila dibandingkan atau dikomparasikan dengan teori dasar sebagaimana digunakan oleh tim peneliti, tentu dalam hal ini PBRP memenuhi kriteria tersebut. Hal tersebut dapat dibuktikan dari hasil penelitian yang ada, dimana telah ditetapkan bahwasanya sebuah pembelajaran PBRP ini mememiliki output berupa video role playing. Dari video role playing tersebut, tentu membutuhkan keterampilan creativity, sebab dari konseptualisasi dialog, pengambilan setting waktu, tempat, hingga berbagai aspek lain dalam role playing membutuhkan tingkat kreativitas yang tinggi dari para pebelajar. Tak lupa, terkait dengan editing video tentu menjadi suatu hal yang mutlak dalam proses role playing. Tak hanya kreativitas saja yang dieksploitasi, namun ketekunan dan konsistensi terhadap editing video yang sifatnya bagus juga perlu untuk dieksploitasi. Sehingga, adanya PBRP ini secara theoretical based sesuai dengan apapran yang ada, yakni dapat meningkatkan atau menciptakan daya berpikir kreatif para pebelajarnya. Berbagai pendapat dari penyusun ini juga senada dengan pendapat dari (Steen-Utheim \& Foldnes, 2018), bahwa bila pembelajaran dihubungkan dengan project maupun penjelasan materi dalam bentuk video, akan menjadikan otak lebih mudah dalam mengasimilasikan hal baru ke dalam neuron, sebab video dapat mengakomodasi gaya belajar read, write, kinesthetics, audio, serta bila seorang pebelajar yang ditugaskan untuk membuat video maka akan muncul keterampilan creativity yang secara implisit digunakan dalam menyelesaikan project ataupun tugas yang terkait.

Poin ke empat, yakni berupa efisiensi pelaksanaan praktik pembelajaran. Efisiensi sendiri diartikan 
oleh (Gunawan \& Benty, 2017) merupakan suatu konsep, dimana bila seseorang atau suatu kegiatan dapat mencapai tujuan dengan alokasi biaya, waktu, dan tenaga yang relatif sedikit, namun dapat mencapai hasil maksimal dapat dikatakan kegiatan maupun seseorang tersebut efisien. Konteks dari pembelajaran PBRP sendiri ini, merupakan sebuah rancangan pembelajaran yang tergolong mudah dan murah untuk dipraktikkan. Mengapa demikian karena (1) pebelajaran atau mahasiswa merupakan generasi $z$, dimana generasi $z$ sendiri adalah generasi yang telah akrab dengan teknologi dalam segala aspek kehidupan (Lissitsa \& Kol, 2016), (2) pebelajar tidak perlu mengeluarkan biaya apapun Ketika melaksanakan pembelajaran ini, karena pebelajar dapat memanfaatkan berbagai platform yang gratis untuk editing video, (3) kemudahan penjelasan materi, hal tersebut tergolong mudah karena bila terdapat hal yang dirasa sulit mahasiswa dapat berkonsultasi dengan dosen dan mahasiswa juga dapat mengikuti video conference dengan dosen guna clarifying dan explaining materi dalam perkuliahan. Dari paparan faktual tersebut tentu telah dapat digeneralisasikan bahwa terkait dengan efisiensi pembelajaran, terpenuhi dengan optimal. Dari penjelasan tim peneliti ditinjau dari theoretical based yang ada, yakni terkait poin pertama hingga ke empat, tentu suatu model pembelajaran ini atau PBRP, selain memenuhi kelayakan dari perspektif validasi ahli, dari segi theoretical based yang ada terkait kriteria model pembelajaran yang baik. Intensitas dari pembelajaran yang ada dalam PBRP tentu diorientasikan pada pola belajar yang condong pada belajar mandiri. Karena memang perkembangan koginitif mahasiswa, sudah memasuki era dewasa dimana terdapat berbagai ciri perkembangan kognitifnya yakni (Hurlock E.B, 2000) (1) mampu berpikir konstruk dengan belajar mandiri, (2) mampu berpikir abstrak sesuai dengan perkembangan ilmu yang dipelajarinya, (3) mampu menghubungkan hubungan antara berbagai disiplin ilmu pengetahuan. Oleh sebab itu juga, pembelajaran demikian dirasa cocok untuk diaplikasikan dalam perkuliahan. Sebab learning by doing the experience menjadi hal yang memiliki urgensi tinggi pada kaitan belajar dan pembelajaran untuk pebelajar yang telah memasuki usia dewasa.

Adanya pembelajaran ini, selain dapat memberikan pengalaman yang menyeluruh sebagai bekalnya ketika telah lulus dari perkuliahan, pembelajaran ini juga dinilai dapat mengakomodasi seorang mahasiswa untuk menjadi pengawas maupun supervisor untuk satuan Pendidikan Ketika dirinya telah lulus di masa yang akan datang. Hal yang tentu dapat dijadikan concern akhir dalam pembahasan ini ialah, berupa bahan ajar yang cederung implikatif. Sebab berbagai bahan ajar telah tersedia di platform belajar dari universitas. Sehingga para siswa bisa hanya melakukan klik untuk mempelajari teori dasar dalam mata kuliah supervisi pengajaran yang dipraktikkan dengan model pembelajaran PBRP. Pengalaman belajar, optimalisasi teknologi, dan optimalisasi fasilitas berupa kuota internet, dengan pembelajaran ini dirasa dapat terakomodasi secara optimal. Maka dari itu, kelayakan dan efisiensi dari pembelajaran ini sudah tidak perlu diragukan lagi, sebab berbagai hal yang ada didalamnya telah (1) tervalidasi oleh ahli, (2) tidak menimbulkan perbedaan persepsi antar mahasiswa, (3) dari segi theoretical based belajar dan pembelajaran telah teruji secara baik, (4) dapat mengakomodasi model belajar yang efektif bagi pebelajar yang telah memasuki masa dewasa dalam perkembangan kognitifnya melalui learning by doing the experience.

\section{Rasional Sintak Pembelajaran PBRP (Problem Based Role Playing)}

Bilamana dibahas secara kompleks mengenai rasional sintak pembelajaran PBRP, yang awalnya berada di 7 tahap, telah dikerucutkan menjadi 6 tahapan dalam pelampiran hasil penelitian. Secara rasional, tahapan tersebut tentu dikerucutkan menjadi 6 tahapan saja, tentu untuk efisiensi pelaksanaan. Sebuah tahapan yang di eliminasi ialah tahapah creating group. Creating group sendiri dalam model pembelajaran ini merupakan tahapan dimana mahasiswa atau pebelaaran pada kaitan ini, membentuk sebuah kelompok untuk pelaksanaan role playing. Hal tersebut menjadi dikerucutkan pada tahap 1 yakni sebuah tahap preparing. Sehingga tahapan yang ada dalam model pembelajaran PBRP ini menjadi 6 tahapan. Selain untuk kemudahan secara administratif terkait rancangan pembelajaran tersebut, dengan 6 tahapan tersebut pun bila dianalisis, tentu telah memenuhi berbagai aspek penting dalam sintak pembelajaran menurut (Winkel, 1989) yakni (1) active experimentation, yang merupakan aspek perencanaan pembelajaran dan memahami materi dasar sebuah pembelajaran, (2) concrete experience, yakni berupa praktik langsung mengenai disiplin ilmu yang dipelajari (3) reflective observation, refleksi berbagai pengalaman belajar dengan teman sebaya dan tutor yang mengampu pelajaran yang terkait, 
(4) abstract conceptualization, mengkonseptualisasi seluruh proses dan membuat konklusi terkait seluruh pembelajaran yang telah dilaksanakan Bersama-sama. Bilamana ditelisik lebih dalam, mengapa sintak pembelajaran yang terkait lebih dikerucutkan secara ringkas, bilamana dihubungkan pada ranah psikis seorang pebelajar di era pandemic, terdapat istilah yang dinamakan burn out. Burn out sendiri merupakan suatu kejenuhan belajar yang kadarnya tinggi di era pandemic, dimana hal tersebut dapat disebabkan oleh (1) kurangnya refreshment dalam hal kogntiif, (2) banyaknya tugas yang diberikan, (3) Langkah pembelajaran yang cukup rumit, (4) mata pelajaran yang sulit tidak diimbangi tutor yang cerdas (DeMatthews, Knight, Reyes, Benedict, \& Callahan, 2020). Bila dianalisis, pada poin ketiga yakni Langkah pembelajaran yang rumit itulah dikerucutkan sintak pembelajaran ini menjadi 6 tahapan, sehingga proses praktiknya lebih sederhana, dan dapat memenuhi aspek efisiensi sebuah belajar dan pembelajaran. Adanya pengerucutan tersebut selain dapat meminimalisir burn out cognitive juga dapat memperbesar peluang ketidak bosanan pebelajar dalam melaksanakan pembelajaran dengan model PBRP.

Dari berbagai gagasan tersebut, tentu suatu hal yang dapat ditarik kesimpulan ialah, dari sintak yang ada, pembelajaran ini selain cocok digunakan dalam pembelajaran Ketika pandemi covid 19 melanda, pembelajaran ini juga cocok untuk digunakan pandemi telah berlalu. Sebab sintak yang ada merupakan sintak yang implikatif dan mengandung 4 aspek urgent dalam sintak pembelajaran sebagaimana telah dideskripsikan pada gagasan di paragraph sebelumnya. Oleh karena itulah terkait dengan adanya pembahasan ini, dapat di konlusikan terkait rasional sintak yang ada dalam PBRP, bahwa (1) rasional sintak PBRP sesuai dengan landasan teori indicator efisiensi sintak pembelajaran, (2) rasional pengerucutan fase dalam PBRP dapat diasumsikan untuk meminimalisir adanya cognitive burn out, (3) validasi ahli menunjukkan hasil yang positif atau baik bagi praktik pelaksanaan PBRP dalam belajar dan pembelajaran di perkuliahan mata kuliah supervisi pengajaran. Fase pertama dan fase kedua dalam sintak pembelajaran PBRP, memenuhi kriteria indicator efisiensi sintak yakni berupa active experimentazion. Dapat dikonklusi demikian, sebab secara garis besar baik dari fase 1 dan fase 2 bahwa pebelajar melakukan tahap pendahuluan dalam pembelajaran, penyiapan awal berbagai proses pembelajaran, elaborasi permasalahan dan penentuan suatu focus permasalahan, dimana hal tersebut masuk dalam kriteria adanya active experimentazion dalam sintak pembelajaran. Setelah itu, fase 3 dan 4 masuk ke dalam krieria concrete experience, karena pada proses yang ada seorang pebelajar melaksanakan actice learning dimana terdapat kegiatan menentukan alternatif penyelesaian, dan praktik pembelajaran role playing secara langsung. Fase ke 5 masuk dalam kriteria reflective observation, sebab dari fase tersebut mengandung proses pembelajaran yang sifatnya refleksi, elaborasi, dan evaluasi bersama.

Setelah itu, fase terakhir atau fase ke 6 menunjukkan bahwa fase tersebut memenuhi seputar aspek atau kriteria sintak pembelajaran yang dinamakan abstract conceptualization, karena hal utama yang dilakukan dalam pelaksanaan fase 6 adalah saling bertukar pengalaman saat role playing dan pemberian feedback baik dari dosen maupun teman sebaya. Hal itulah yang menyebabkan sebuah pembelajaran ini memenuhi berbagai indicator baik dalam hal sintak pembelajaran bila ditinjau dari teori sebagaimana telah disebutkan oleh (Winkel, 1989). Berikut adalah visualisasi terkait dengan kriteria yang terpenuhi dalam pembelajaran PBRP.

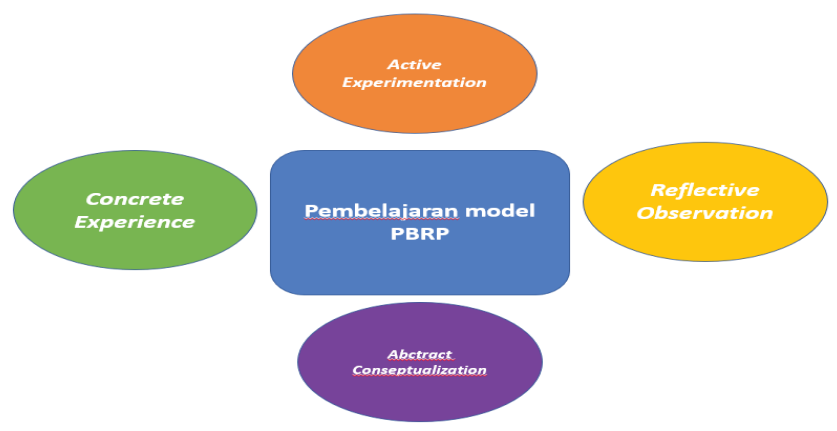

Gambar 1 Aspek Kriteria Sintak yang Terpenuhi 


\section{Dampak Positif Model Pembelajaran PBRP pada Mahasiswa}

Bilamana berbicara mengenai dampak positif pada pembahasan ini, maka tim peneliti hendak memaparkan berbagai dampak yang ada berlandaskan pembahsan sebelum-sebelumnya, yakni dilandaskan pada bahan ajar yang ada, sintak pembelajaran yang diimplementasikan, serta model pembelajaran yang ada. Bila dianalisis secara menyeluruh dari fase awal hingga akhir, maka tim peneliti hendak memberikan gagasan, bahwa model pembelajaran ini sesuai dengan perkembangan zaman yang ada, sebab terdapat berbagai alasan didalamnya yakni (1) pemenuhan aktualisasi kemampuan 4C seorang mahasiswa (critical thinking, communication, collaboration, creativity), (2) mewujudkan efikasi diri mahasiswa, (3) mewujudkan mental attainment pada pebelajar. Pembelajaran PBRP (Problem Based Role Playing) merupakan sebuah pembelajaran yang didalamnya terinternalisasi sebuah model pembelajaran problem based learning dan role playing. Bilamana ditinjau dari sintak pembelajaran yang ada dari fase ke 1 hingga ke 6 suatu hal yang dapat diambil benang merah ialah (1) pembelajaran PBRP menuntut siswanya aktif melalui learning by doing the experience, (2) pembelajaran PBRP telah dipersiapkan begitu kompleks untuk eksternalsiasi creativity seorang pebelajar, (3) menuntut kerja kelompok untuk menyelesaikan tugas dan permasalahan yang ada, (4) output tugas terstruktur adalah sajian video kreatif mengenai praktik pelaksanaan supervise pengajaran. Secara sederhana tentu hal tersebut akan mengarah pada pembentukan keterampilan $4 \mathrm{C}$, sebab dalam proses pembelajran yang ada dari awal hingga akhir, seorang pebelajar dituntut untuk mengembangkan critical thinking nya, dimana dimanifestasikan dalam berbagai kegiatan yakni (1) evaluasi sajian vidio oleh teman sebayanya, (2) elaborasi materi pembelajaran, (3) analisis permasalahan yang sifatnya faktual, (4) proses bertukar pengalaman saat selesai mengerjakan seluruh tugas.

Maka dari itulah tim peneliti hendak menegaskan bahwasanya PBRP dapat mengeksternalisasi critical thinking pebelajar. Kemudian, terkait dengan communication, tentu secara jelas dapat ditelaah bersama, bahwa keterampilan komunikasi dapat terkeksternalisasi optimal karena pendekatan yang digunakan adalah kolaboratif, sehingga dalam role playing yang ada, seorang mahasiswa atau pebelajar harus berlatih dahulu untuk optimalisasi sebuah keterampilan komunikasi. Sehingga secara tidak sadar pebelajar telah terkesternalisasi kemampuan komunikasinya. Pada collaboration, termanifestasikan dalam kegiatan berkelompok, serta evaluasi, dan bertukar pengalaman belajar kepada peer dalam kelas. Yang terakhir, ialah creativity dimana hal tersebut tereksternalisasi dengan baik Ketika pelaksanaan tahap 1 pada sintak, hingga tahap 6, sebab pebelajar dituntut kreatif dalam (1) menemukan masalah, (2) menyelesaikan masalah, (3) mengkonseptualisasikan komunikasi dalam role playing, (4) editing video. Dengan demikian dapat dikategorikan bahwa pembelajaran ini, yakni PBRP, senada dengan perkembangan industrial revolustion 4.0, khususnya dalam Pendidikan. Pendapat ini didukung oleh pendapat dari (Wrahatnolo \& Munoto, 2018), bahwa pembelajaran yang baik di era sekarang, ialah bukan pembelajaran yang mentransformasikan keterampilan what saja, namun dapat melaksanakan deliver untuk pembentukan (1) creativity, (2) critical thinking, (3) collaboration, (4) communication. Maka dari itulah peneliti merumuskan gagasan yang sedemikian rupa, yakni untuk menegaskan bahwa PBRP juga memiliki dampak yang Panjang bagi peningkatan keterampilan pebelajarnya. Kemudian setelah dibahas mengenai keterampilan 4C, maka akan dibahas terkait dengan mental attainment. Perlu dijelaskan sendiri bahwasanya mental attainment dalam ranah pembelajaran atau psikologi Pendidikan sendiri menurut (Oettingen et al., 2009) adalah kondisi psikologis dimana seorang siswa menjadi fokus dan memiliki komitmen tinggi dala belajar. Lawan dari mental attainment ini adalah mental contrasting, dimana seorang siswa cenderung malas dan tidak fokus dalam melaksanakan pembelajaran. Melalui model pembelajaran PBRP inilah seorang siswa menjadi memiliki mental attainment. Hal ini tentu berhubungan langsung dengan eksternalisasi dari keterampilan $4 \mathrm{C}$, jadi keterampilan $4 \mathrm{C}$ yang dapat membentuk berbagai keterampilan siswa, akan mempengaruhi siswa untuk senantiasa fokus dan senantiasa termotivasi untuk melaksanakan suatu proses belajar yang konsisten. Sebuah fokus yang tinggi tersebut, disebabkan oleh sistemasi yang optimal, serta tugas yang diberikan sifatnya learning by doing the experience.

Oleh karena itu, tim peneliti dapat menggeneralisasi bahwasanya model pembelajaran PBRP dapat membentuk mental attainment siswa. Kemudian untuk poin terakhir, seperti telah diketahui 
yakni efikasi diri. Efikasi diri sendiri adalah sebuah kemampuan berupa keyakinan bahwa seorang individu yang terkait dapat memiliki keyakinan diri akan seluruh kapabilitasnya (Fatimah, 2006). Dapat diartikulasikan demikian, sebab terkait dengan efikasi diri ini, dapat dibentuk setelah siswa mendapatkan elaborasi, evaluasi, dan berbagai komunikasi di dalam pelaksanaan pekerjaan tugasnya. Disamping itu, keterampilan 4C siswa telah tereksternalisasi dengan optimal melalui pembelajaran PBRP, sehingga hal ini dapat dijadikan asumsi dasar, bahwa keterampilan berpikir kritis, komunikasi, kolaborasi, dan kemampuan kreativitas itulah yang dapat membentuk efikasi diri seorang pebelajar melalui model pembelajaran PBRP. Adanya tiga dampak tersebut, tentu dapat menjadikan seorang siswa menjadi lebih konsisten dalam belajar, serta akan merasa bahwa pembelajaran semacam demikian memiliki nilai pragmatic yang tinggi. Sehingga dalam pelaksanannya, dan proses belajar pebelajar kedepan, akan selalu memandang bahwa ilmu merupakan suatu hal yang patut untuk ditelisik secara sungguh-sungguh, karena kebermanfaatannya. Dengan demikian, dapat disepakati bahwa sebuah model pembelajaran yang baik, baik setelah dilaksanakan sebuah validasi ahli, maupun dilaksanakan kajian dari theoretical based akan tetap memiliki sisi positifnya. Serta akan memiliki, dampak yang Panjang dan positif untuk pebelajar didalamnya.

\section{SIMPULAN}

Berdasarkan hasil penelitian pengembangan yang telah dilakukan sesuai dengan prosedur pengembangan melalui enam langkah dapat disimpulkan bahwa penelitian pengembangan model pembelajaran Problem Based Role Playing (PBRP) telah selesai dilaksanakan sampai dengan tahap akhir sehingga menjadi produk final yang dapat digunakan sebagai model pembelajaran pada mata kuliah supervisi pengajaran. Model PBRP ini merupakan pengembangan model pembelajaran aktif yang memadukan dua model pembelajaran aktif yaitu problem based learning dan role playing. Adapun hasil pengembangan dalam penelitian ini meliputi sintak implementasi PBRP dan video bahan ajar berupa kegiatan mahasiswa bermain peran pada mata kuliah supervisi pengajaran. Hasil pengembangan tentang sintak PBRP meliputi enam fase yang terdiri dari: Preparing, Problems Analyse, Problems Finding and Problems Solving, Division of roles, Discussion and evaluation, Share experience and conclusions. Berdasarkan hasil validasi yang dilakukan oleh ahli serta uji coba produk yang dilakukan kepada mahasiswa diperoleh data bahwa produk pengembangan berupa video bahan ajar dan sintak implementasi PBRP dalam kategori baik. Dengan demikian maka produk yang dihasilkan dalam penelitian pengembangan ini layak untuk di implementasikan pada perkuliahan supervisi pengajaran.

\section{REFERENCE}

Afandi, M., Chamalah, E., \& Puspita Wardani, O. (2013). Model \& Metode Pembelajaran di Sekolah. In Unissula Press.

Anggraeni, A. D. (2018). Metode Role Playing dalam Pembelajaran Profesi Kependidikan. Jurnal Pendidikan Progresif, Vol. 8, pp. 29-35. LPPM Universitas Lampung. https://doi.org/10.23960/jpp.v8.i1.201804

Armstrong, e. K. (2003). Applications of Role-Playing in Tourism Management Teaching: An Evaluation of a Learning Method. The Journal of Hospitality Leisure Sport and Tourism, 2(1), 5-16. https://doi.org/10.3794/ johlste.21.24

Burden, P. R \& Byrd, D. M. (2013). Methods for Effective Learning. New York: Pearson Education Inc.

DeMatthews, D., Knight, D., Reyes, P., Benedict, A., \& Callahan, R. (2020). From the Field: Education Research During a Pandemic. Educational Researcher, 49(6), 398-402. https://doi.org/10.3102/0013189X20938761

Errington, E. (1997). Role-play in higher education. Role-Play, 47-50.

Fatimah, E. (2006). Psikologi Perkembangan. Bandung: CV. Pustaka Setia.

Gijbels, D., Dochy, F., Van den Bossche, P., \& Segers, M. (2005). Effects of Problem-Based Learning: A MetaAnalysis From the Angle of Assessment. Review of Educational Research, 75(1), 27-61. https://doi. org/10.3102/00346543075001027

Greenberg, E. and Miller, P. (1991). The Player and the Professor: Theatrical Techniques in Teaching. Journal of Management Education, 15(4), 428-46. 
Gunawan, I. (2013). Metode Penelitian Kuantitatif. Jakarta: Bumi Aksara.

Gunawan, I., \& Benty, D. D. N. (2017). Manajemen Pendidikan Suatu Pengantar Praktik. Alfabeta.

Hurlock E.B. (2000). Psikologi Perkembangan. Jakarta: Erlangga.

Kolb, D. (2007). Experiential Learning: Experience as the Source of Learning and Development (terjemahan Bahasa Indonesia). Jakarta: Gramedia.

Lissitsa, S., \& Kol, O. (2016). Generation X vs. Generation Y :z A decade of online shopping. Journal of Retailing and Consumer Services, 31, 304-312. https://doi.org/10.1016/j.jretconser.2016.04.015

Mawardi. (2018). Merancang Model dan Media Pembelajaran. Jurnal Pendidikan Dan Kebudayaan, 8, 26-40. https://doi.org/https://doi.org/10.24246/j.js.2018.v8.i1.p26-40

Nurdyansyah dan Eni Fariyatul Fahyuni. (2016). Inovasi Model Pembelajaran (Pertama). Sidoarjo: Nizamia Learning Center.

Oettingen, G., Mayer, D., Timur Sevincer, A., Stephens, E. J., Pak, H. J., \& Hagenah, M. (2009). Mental contrasting and goal commitment: The mediating role of energization. Personality and Social Psychology Bulletin, 35(5), 608-622. https://doi.org/10.1177/0146167208330856

Phelan, A. M. (2015). Curriculum Theorizing and Teacher Education. In Teacher Education Systems in Africa in the Digital Era. https://doi.org/10.4324/9780203387078

Prestiadi, D., Maisyaroh, Arifin, I., \& Bhayangkara, A. N. (2020). Meta-Analysis of Online Learning Implementation in Learning Effectiveness. Proceedings - 2020 6th International Conference on Education and Technology, ICET 2020, 109-114. https://doi.org/10.1109/ICET51153.2020.9276557

Prestiadi, D., Maisyaroh, Zulkarnain, W., Nurabadi, A., Arifin, I., Jafar, R. H. A., \& Lutfi, M. Z. (2020). The Effectiveness of Online Learning at SIPEJAR Using Video-Based Learning Media. 508(Icite), 535-540. https://doi.org/10.2991/assehr.k.201214.291

Sallis, E. (2014). Total quality management in education: Third edition. In Total Quality Management in Education: Third Edition. https://doi.org/10.4324/9780203417010

Sari, F. F. K. (2018). Peningkatan Hasil Belajar Siswa SD pada Pembelajaran Tematik melalui Penerapan Model Pembelajaran Role Playing. Satya Widya, Vol. 34, pp. 62-76. Universitas Kristen Satya Wacana. https://doi. org/10.24246/j.sw.2018.v34.i1.p62-76

Setiawati, L. (2016). Implementasi Role Playing Dalam Meningkatkan Hasil Belajar. Pedagogia, 14(2), 318-332. https://doi.org/10.17509/pedagogia.v14i2.3881

Sinanglingtyas, R. (2013). Penerapan Metode Role playing untuk Meningkatkan Aktivitas dan Hasil Belajar Siswa Kelas V dalam Pembelajaran PKn Pokok Bahasan Bentuk-Bentuk Keputusan Bersama di SDN Tukum 01 Lumajang. Jurnal Pendidikan UNEJ, 1(1), 1-5.

Steen-Utheim, A. T., \& Foldnes, N. (2018). A qualitative investigation of student engagement in a flipped classroom. Teaching in Higher Education, 23(3), 307-324. https://doi.org/10.1080/13562517.2017.1379481

Sugiyono. (2019). Metode Penelitian Kuantitatif, Kualitatif dan R\& D (Sutopo, Ed.). Bandung: Alfabeta.

Walter Borg \& Meredith Gall. (1995). Educational Research: An Introduction (Fifth Edit). Harlow: Pearson Education Inc.

Winkel, W. S. (1989). Psikologi Pendidikan dan Evaluasi Belajar. Jakarta: Gramedia.

Wiyono, B.B., \& S. (2009). Evaluasi Program Pendidikan dan Pembelajaran. Malang: Fakultas Ilmu Pendidikan Universitas Negeri Malang.

Wrahatnolo, T., \& Munoto. (2018). 21st centuries skill implication on educational system. IOP Conference Series: Materials Science and Engineering. https://doi.org/10.1088/1757-899X/296/1/012036

Yehuda Baruch. (2006). Role-play Teaching. Management Learning, 37(1), 43-61.

Zadina, J. N. (2014). Multiple pathways to the student brain: Energizing and enhancing instruction. In Multiple pathways to the student brain: Energizing and enhancing instruction. 